\title{
APPLICATION OF PHYTASES FROM BIFIDOBACTERIA IN THE DEVELOPMENT OF CEREAL-BASED PRODUCTS WITH AMARANTH
}

Izaskun García-Mantrana $^{12}$, Vicente Monedero ${ }^{2}$ and Monika Haros ${ }^{1^{*}}$

${ }^{1}$ Cereal Group; ${ }^{2}$ Lactic Acid Bacteria and Probiotics Laboratory, Instituto de Agroquímica y Tecnología de Alimentos (IATA-CSIC), Valencia, Spain.

*Corresponding author (Tel: +34 9639000 22; Fax: +34 9636363 01; E-mail: mharos@iata.csic.es 


\section{ABSTRACT}

The effects of the inclusion of purified phytases from Bifidobacterium longum spp. infantis ATCC15697 and Bifidobacterium pseudocatenulatum ATCC27919 on phytate $\left(\operatorname{Ins} P_{6}\right)$ levels were analyzed during breadmaking process. Two different levels of whole amaranth (Amaranthus cruentus) flour (25 and 50\%) were used in bread dough preparation and they were compared to control doughs made with $100 \%$ wheat flour and $100 \%$ whole wheat flour. Bread samples made with $50 \%$ of amaranth flour showed a significant decrease in technological quality parameters in comparison to control white breads. However, a $25 \%$ of amaranth flour improved the nutritional value of the bread, with only a slight depreciation in the quality. Addition of bifidobacterial phytases resulted in higher $\operatorname{Ins} P_{6}$ degradation compared to a commercial fungal phytase, without affecting the bread quality. $\operatorname{Ins} P_{6}$ reduction was especially efficient in breads with $25 \%$ amaranth, leading to $\operatorname{Ins} P_{6}$ levels below the threshold of mineral bioavailability inhibition for Fe and $\mathrm{Zn}$ in human nutrition.

KEYWORDS: whole amaranth flour, bread, phytates, bifidobacterial phytase, mineral availability 


\section{INTRODUCTION}

Cereals and their derivatives constitute a considerable part of a balanced diet and are at the first level in the food pyramid, according to the international dietary guidelines. Cereal grain products are divided into two categories: refined and whole grain products. Refined grains possess a limited nutritional value, whereas whole grains are a better source of fibre, vitamins, minerals, and contain also a variety of other phytochemicals and antioxidants [1-3]. Due to this fact, an increasing interest exists in the development of dietary fibre-rich cereal products with this nutritional added value. In addition, epidemiological studies confirmed that consumption of whole grain cereals and pseudocereals is associated with reduced risk of type-2 diabetes, constipation, obesity, cardiovascular diseases and some types of cancer [4].

One possibility for increasing the nutritional value of bakery products could be the inclusion of whole amaranth grain in their formulations. Amaranthus is a common flowering plant genus that yields the nutritious staple amaranth grain, a pseudocereal [5]. This genus comprises more than 60 species, but only three of them are usually used for human consumption: Amaranthus caudatus, A. cruentus and $A$. hypocondriacus [5]. The nutritional quality of amaranth grain is significantly higher when compared with most cereal seeds such us wheat, barley or rice. Compared to wheat flour, A. cruentus flour possesses a significantly higher protein (14-18\%), lipid (6-8\%) and dietary fibre (11-23\%) contents and it also contains vitamins, minerals and other biologically active compounds [6,7]. The balanced essential amino acid composition is also a characteristic of amaranth seeds [8]. Furthermore, amaranth grain protein is rich in lysine content, a deficient amino acid in cereals. The lipid content (6-8\%) is 
also higher than that of most cereal grains, with an enhanced presence of unsaturated oil (45\% linoleic acid) which plays an important role in cardiovascular health [9]. In addition to these nutritional components, amaranth seed also contains other organic compounds such as tocotrienols, squalene and phytosterols, involved in the metabolism of cholesterol, and able to lower LDL-cholesterol levels and plasma triglycerides concentration [10]. Aside from these substances amaranth seeds count with bioactive peptides with antihypertensive effect and with the anticarcinogenic properties of the peptide lunasin [11] and their lack of gluten make them ideal for the manufacture of products for celiacs. However, whole grains contain significant amounts of phytic acid [myo-inositol $(1,2,3,4,5,6)$-hexakisphosphate or $\operatorname{Ins} P_{6}$ ] or its salts (phytates), a well-known inhibitor of mineral, proteins and trace elements bioavailability [12]. The negative effects of phytates in human nutrition are more relevant in developing countries, in risk populations such as pregnant women or those who follow an unbalanced diet and also in animal feed $[13,14]$. The phytic acid is an organic acid common in plants in which it functions in the storage of phosphorus and cations for growth [15]. Phytic acid has a strong ability to form complexes with bi/multivalent metal ions, especially iron, calcium and zinc $[16,17]$. A partial dephosphorylation of phytates not only decreases this negative effect, but also generates lower myo-inositol phosphates with potential benefits to human health $[18,19]$. Phytases are a class of phosphatases that catalyze the sequential hydrolysis of $\operatorname{Ins} P_{6}$ to lower myo-inositol phosphates and inorganic phosphate [19]. There are several strategies to increase the phytase activity present in raw materials. Thus, cereals have their own endogenous phytase and the addition of sourdough into breadmaking process 
improves the degradation of phytates, due to the decrease of $\mathrm{pH}$ [20]. Aside from the own cereal phytase, the addition of an exogenous phytase (generally from microbial sources) is other alternative. This strategy is broadly used in feed production for monogastric animals and it has also been explored in the production of cereal and legume foods for human consumption [21]. Phytase activity has been described for food-grade strains of the genus Bifidobacterium, and these bacteria have been applied in both direct and indirect breadmaking processes [20,22]. Bifidobacterium longum spp. infantis ATCC15697 and Bifidobacterium pseudocatenulatum ATCC27919 bacterial cells demonstrated their efficacy in the reduction of phytates in breads and increased iron availability in both processes $[20,22]$. The genes encoding these phytases have been recently cloned and the enzymes purified and characterized, showing that they belong to the histidine-acid phosphatase family and possess distinctive biochemical characteristics, such as a remarkable thermal stability and the ability to degrade $\operatorname{Ins} P_{6}$ to $\operatorname{Ins} P_{3}$ [23]. The inclusion of these purified phytases in the process of production of infant cereals resulted in a significant decrease in Ins $P_{6}$ contents and an enhanced solubility of zinc [22].

The objective of the present investigation was to develop new bakery cerealbased products with improved nutritional quality. To this end, breads were made with addition of whole amaranth flour. In these breads the undesirable effects of the high level of phytates found in amaranth seeds were avoided by including purified phytases from intestinal bifidobacteria during the process. The likely contribution of the product to mineral intake, according to the daily reference intake (DRI) and its possible overestimation by the presence of phytates, was also evaluated. 


\section{MATERIALS AND METHODS}

\section{Materials}

Commercials flours were purchased from the local market. The characteristics of wheat, whole wheat and whole amaranth flours (Amaranthus cruentus) were: moisture, $14.53 \pm 0.03,14.04 \pm 0.08$ and $11.89 \pm 0.04 \%$; protein, $13.6 \pm 0.1$, $11.6 \pm 0.1$ and $14.9 \pm 0.1 \%$ in dry basis; fat, $1.30 \pm 0.09,1.67 \pm 0.03$ and $5.60 \pm 0.04$ $\%$ in dry basis; ash, $0.62 \pm 0.03,1.36 \pm 0.01$ and $2.94 \pm 0.08 \%$ in dry basis; and phytate contents were: not detected, $7.5 \pm 0.1$ and $13.3 \pm 0.3 \mu \mathrm{mol} \mathrm{g}{ }^{-1}$ in dry basis, respectively. The flour alveograph parameters were: tenacity, $\mathrm{P}: 81 \mathrm{~mm}$; extensibility, L: $110 \mathrm{~mm}$; P/L ratio, 0.74; and deformation work, $\mathrm{W}: 308 \times 10^{-4} \mathrm{~J}$. Compressed yeast (Saccharomyces cerevisiae, Levamax, Spain) was used as starter. Commercial fungal phytase (E.C 3.1.3.8) from Aspergillus niger produced by submerged fermentation of a genetically modified Aspergillus oryzae (73 $\mathrm{U} \mathrm{ml}^{-1}$, Ronozyme Phytase from Novozymes, Bioindustrial, Madrid, Spain) was used as a positive control in dough formulations. Recombinant phytases enzymes expressed in Escherichia coli clones carrying the phytase genes from Bifidobacterium longum spp. infantis ATCC 15697 and Bifidobacterium pseudocatenulatum ATCC 27919, originally isolated from infant faeces, were also used (see below).

\section{Expression of bifidobacterial phytases}

The phytases from bifidobacteria were overexpressed in E. coli as 6xHis-tagged proteins lacking their $\mathrm{N}$-terminal signal peptides and $\mathrm{C}$-terminal cell-wall anchor endogenous sequences [23]. E. coli M15 clones carrying the recombinant 
plasmids (pQE80 derivatives) were grown in $500 \mathrm{ml}$ of LB medium with ampicillin at $100 \mu \mathrm{g} \mathrm{ml}^{-1}$ at $37^{\circ} \mathrm{C}$ under shaking, until an optical density of 0.6 at $600 \mathrm{~nm}$ was reached. The expression of the phytases was induced by adding isopropyl $\beta$-D-1-thiogalactopyranoside (IPTG) to $0.1 \mathrm{mM}$ and incubating at $30^{\circ} \mathrm{C}$ for 4 hours. After centrifugation, the obtained bacterial cell pellets were washed with $0.9 \% \mathrm{NaCl}$, resuspended in $100 \mathrm{mM}$ Tris- $\mathrm{HCl} \mathrm{pH} 7.4$ buffer containing 1 $\mathrm{mg} \mathrm{ml}^{-1}$ lysozyme and incubated at $37^{\circ} \mathrm{C}$ for $30 \mathrm{~min}$. Bacterial cells in this suspension were broken by sonication and after removing the cellular debris by centrifugation at $15000 \mathrm{xg} 15 \mathrm{~min}$ at $4^{\circ} \mathrm{C}$, the supernatants were filtered through $0.45 \mu \mathrm{m}$-pore-size nitrocellulose filters. Filtered supernatants were applied to $\mathrm{Ni}$ NTA agarose chromatography columns ( $1 \mathrm{ml}$ bed volume), and recombinant proteins were purified according to the supplier instructions (Qiagen). After several washes, proteins were eluted from the columns in $1 \mathrm{ml}$ fractions that were analyzed by SDS-PAGE. The fractions containing the expressed proteins were dialyzed against $100 \mathrm{mM}$ Tris- $\mathrm{HCl} \mathrm{pH}$ 7.4, $1 \mathrm{mM}$ EDTA, 10\% glycerol and $50 \mathrm{mM} \mathrm{NaCl}$ at $4^{\circ} \mathrm{C}$ for $24 \mathrm{~h}$ and stored at $-80^{\circ} \mathrm{C}$ until use.

\section{Determination of phytase activity}

The enzymatic flour extracts were prepared following the method reported by Haros et al. [24]. The phytase activity was determined using $500 \mu \mathrm{l}$ of $0.1 \mathrm{M}$ sodium acetate $\mathrm{pH} 5.5$, containing $1.2 \mathrm{mM}$ potassium phytate and $100 \mu \mathrm{l}$ fractions of each purified enzyme or flour extracts [24,25]. After 15 minutes of incubation at $50^{\circ} \mathrm{C}$, the reaction was stopped by adding $100 \mu \mathrm{l}$ of $20 \%$ trichloracetic acid, allowed to stand for $10 \mathrm{~min}$ at $0^{\circ} \mathrm{C}$ and centrifuged at 14000xg, $5 \mathrm{~min}$ and $4^{\circ} \mathrm{C}$ (Centrifuge 5415R, Eppendorf AG, Hamburg, 
Germany). The determination of the enzyme activity was based in a colorimetric quantification at $400 \mathrm{~nm}$ of free phosphorus released by the hydrolysis of phytate using ammonium molybdovanadate reagent (Fluka Chemika) according to Tanner et al. [26]. One unit of phytase activity (U) was defined as the amount of enzyme releasing $1 \mathrm{mg}$ of phosphorous from phytate per minute at $\mathrm{pH} 5.5$ and $50^{\circ} \mathrm{C}$. Determinations were carried out in duplicate.

\section{Determination of myo-inositol phosphates}

Ins $P_{6}$ present in flours and the remaining $\operatorname{Ins} P_{6}$ and lower myo-inositol phosphates generated during the breadmaking process were extracted by ionexchange chromatography and measured by high pressure liquid chromatographic methods described by Türk and Sandberg [27], later modified by Sanz-Penella et al. [28]. Identification of the myo-inositol phosphates was achieved by comparison with standards of phytic acid di-potassium salt (SigmaAldrich, St. Louis, MO). Samples were analyzed in triplicate.

\section{Determination of minerals in bread samples}

The total $\mathrm{Fe}, \mathrm{Ca}$ and $\mathrm{Zn}$ concentrations in bread samples were determined using a flame atomic absorption spectrometer at the Servei Central de Suport a la Investigació Experimental from the University of Valencia. Previously, samples were placed in a Teflon perfluoroalkoxy (PFA) vessel and treated with $1 \mathrm{~mL} \mathrm{HNO}_{3}$ (14M, Merck) and $1 \mathrm{~mL}$ of $\mathrm{H}_{2} \mathrm{O}_{2}(30 \% \mathrm{v} / \mathrm{v}$, Panreac Química, Spain). The Teflon PFA vessel was irradiated at $800 \mathrm{~W}$ (15 min at $\left.180^{\circ} \mathrm{C}\right)$ in a microwave accelerated reaction system (MARS) from CEM (Vertex, Spain). At 
the end of the digestion program, the digest was placed in a tube and made up to volume with $0.6 \mathrm{M} \mathrm{HCl}$ (Merck). Samples were analyzed in triplicate.

\section{Breadmaking process}

Four flour formulations were used for bread doughs: 100\% wheat flour (WF), $100 \%$ whole wheat flour (WWF), $25 \%$ whole amaranth flour and $75 \%$ wheat flour (WAF25), and 50\% whole amaranth flour and 50\% wheat flour (WAF50). The bread dough formula expressed in flour basis consisted of different flour formulations $(300 \mathrm{~g})$, compressed yeast $(5 \%)$, sodium chloride $(1.6 \%)$ and water up to optimum absorption corresponding to $500 \mathrm{BU}$ (Brabender Units) (between $60 \%$ and $66.8 \%$ depending on bread dough formulation). A sponge method mixing dough in a two stage was used (Figure 1). The first stage involved mixing half water and flour amount together with the total yeast amount and fermenting for $24 \mathrm{~h}$ at $4^{\circ} \mathrm{C}$. The sponge is then mixed in with the rest of ingredients in a second stage. The ingredients were mixed for 5.5-6.0 min, rested for $10 \mathrm{~min}$, divided into $100 \mathrm{~g}$ pieces, kneaded and then rested again for 15 min. Doughs were manually sheeted, rolled and fermented up to the optimum volume increase at $28^{\circ} \mathrm{C}$ and $80 \%$ of relative humidity. Finally, the

samples were baked at $180^{\circ} \mathrm{C} / 20 \mathrm{~min}, 165^{\circ} \mathrm{C} / 30 \mathrm{~min}, 160^{\circ} \mathrm{C} / 35 \mathrm{~min}$, and $160^{\circ} \mathrm{C} / 30 \mathrm{~min}$ for WF, WWF, WAF25 and WAF50, respectively, and cooled at room temperature for $75 \mathrm{~min}$. The formulation samples were done in duplicate. The different phytases were added during mixing at a concentration equivalent to the phytase endogenous activity in the flours (Figure 1).

\section{Bread quality}


The technological parameters analyzed were moisture (\%), loaf specific volume $(\mathrm{ml} / \mathrm{g})$, width/height ratio of the central slice $(\mathrm{cm} / \mathrm{cm})$ and crumb firmness $(\mathrm{N})$ using texture analyzer TA-XT plus. The colour parameters $L^{*}$ (lightness), $a^{*}$ (redness to greenness) and $b^{*}$ (yellowness to blueness) of crumb and crust were determinate using a digital colorimeter (Chromameter CR-400, Konika Minolta Sensing, Japan) [22]. From the colour parameters the total colour difference $\left(\Delta \mathrm{E}^{*}\right)$ was calculated with the formula: $\Delta \mathrm{E}^{*}=\left[\left(\Delta \mathrm{L}^{*}\right)^{2}+\left(\Delta \mathrm{a}^{*}\right)^{2}+\right.$ $\left.\left(\Delta \mathrm{b}^{\star}\right)^{2}\right]^{1 / 2}$. Samples were analysed at least in triplicate.

\section{Statistical analysis}

Multiple sample comparison of the means and Fisher's least significant differences (LSD) were applied to establish significant statistical differences between treatments. All statistical analyses were carried out with the Statgraphics Plus 7.1 software (Bitstream, Cambridge, MN) and differences were considered significant at $p<0.05$.

\section{RESULTS AND DISCUSSION}

Technological quality of breads containing amaranth flours and microbial phytases

The characteristics of whole amaranth-wheat mixed bread and the effect of the inclusion of bifidobacterial phytases on bread quality was investigated. The quality of the final products was analyzed by measuring technological parameters such as moisture, loaf specific volume, width/height ratio of the central slice, crust and crumb colour and crumb firmness and compared to control breads made with wheat or whole wheat flours. 
The moisture parameters for whole wheat breads (WWF samples) were between 30.8 and $33.8 \%$. Moisture of wheat flour breads (WF samples) was $33.1 \%$, whereas in breads containing $25 \%$ and $50 \%$ of whole amaranth flour (WAF25 and WAF50 samples) moisture ranged between 30.4 to $33.6 \%$ and 32.5 to $34.3 \%$, respectively (Table 1 ). In general, when the levels of whole grain flours or bran are increased, the water retention capacity of doughs is higher compared to refined flours [28]. However, in the current investigation a strong flour with high protein content (13.6\%) was used, which accounts for a higher water absorption in the wheat flour breads.

A decrease in the bread quality was observed by the use of whole wheat flour and whole amaranth flour (Table 1). The presence of these whole grain flours produced significant changes in specific volume and in crumb firmness, especially in WWF and WAF50 samples (Table 1). These changes were related to the gluten content decrease in these formulations. Crumb firmness is a quality parameter in bakery products that is closely related to the tenderness perception by the consumer [29]. Samples with $50 \%$ of amaranth (WAF50) were the most affected, with a 2.8- to 3.8-fold increase in firmness and 1.3- to 1.6-fold decrease in specific volume compared to bread made with wheat flour (WF, Table 1). However, the inclusion of $25 \%$ of amaranth flour (WAF25) resulted in technological parameters closer to the control white bread. Thus, WAF25 samples displayed significantly lower firmness and higher specific volume compared to WWF samples (Table 1).

The colour of both whole grain flours showed a lower lightness than the wheat flour without significant differences between them. The values were $84 \pm 2 ; 78 \pm 4$ and $79 \pm 3$ for wheat, whole wheat and whole amaranth flour, respectively. The 
amaranth flour colour parameters showed a slight increase in the yellowness (data not shown). This was related to the presence of natural pigments such as flavonoids and other polyphenols, especially present in the whole amaranth flour, which were responsible for the changes in the crust and crumb colour observed in breads [30]. In general, the tristimulus colour values in crust and crumb were affected by the inclusion of amaranth. The crust redness was significantly higher when the whole grain flour concentration was increased, especially with the increase in amaranth content (values of $a^{*}$ ranging from $4.9 \pm 0.2$ to $14.1 \pm 0.7$ for WF and WAF50 breads, respectively). On the other hand, the crust lightness decreased significantly with the inclusion of whole amaranth (from $65 \pm 2$ to $51 \pm 1$ ), whereas the yellowness remained around 32 .

The crumb tristimulus colour parameters were more affected than the crust parameters by the inclusion of amaranth flour. The values of $a^{*}$ varied from $1.5 \pm 0.3$ to $1.8 \pm 0.3$ for WF and WAF50 breads, respectively, while the breads made with $100 \%$ whole wheat flour (WWF) had the higher values of redness (3.6 \pm 0.5$)$. The inclusion of $25 \%$ or $50 \%$ of whole amaranth flour in bread formulations did not affect significantly the crumb lightness. However, crumb lightness in whole wheat bread $(55 \pm 2)$ was significantly lower than in control

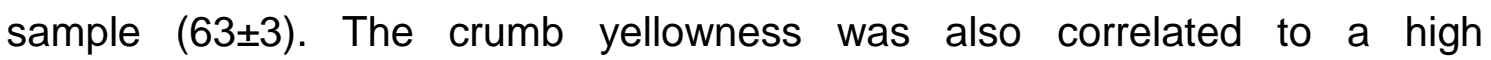
concentration of amaranth flour, probably due to a higher content of flavonoids ( $b *$ value was $24.7 \pm 0.7$ for WAF50 breads, whereas they were $12.9 \pm 0.6$ and $17.7 \pm 0.8$ for WF and WWF breads, respectively). The total colour difference between samples (crust and crumb colour), $\Delta \mathrm{E}$, were higher than 5 units, indicating that significant differences are perceptible to consumers by visual 
observation [20]. The phytase treatment did not show significant differences in colour parameters compared to control (results not shown).

With the exception of some specific conditions, the technological parameters did not change with the addition of the different microbial phytases (control fungal phytase and bifidobacterial phytases). The differences comprised an increased firmness in WWF breads treated with both types of phytases, compared to the same untreated samples (Table 1). This behaviour was not observed in breads with amaranth flour, although no clear explanation for this could be hypothesized. Another change was represented by a slight increment in loaf volume in formulations with amaranth and treated with phytases compared to untreated samples (Table 1). This effect was significantly higher in the WAF50 formulation. Haros et al. [31] hypothesized that an advanced hydrolysis of phytate could activate the wheat endogenous alpha-amylase through calcium liberation, which acts as cofactor of this enzyme. This leads to an increase in the volume of the bakery pieces during the fermentation process. Finally, the width/height ratio of the central slice remained constant in all the formulations, except in the WAF50 breads, where higher values were obtained in samples not treated with phytases (Table 1).

\section{Effect of bifidobacterial phytases on the myo-inositol phosphates levels in bread}

The whole grain flours used in this study contained high levels of phytate (whole wheat, $7.5 \pm 0.2 \mu \mathrm{mol} \mathrm{g}{ }^{-1}$; whole amaranth, $13.3 \pm 0.4 \mu \mathrm{mol} \mathrm{g}{ }^{-1}$ of $\left.\operatorname{lns} P_{6}\right)$. However they also showed a high endogenous phytase activity (whole wheat, 18.8 $\pm 0.5 \mathrm{U}$ $\mathrm{g}^{-1}$; whole amaranth, $22.0 \pm 0.8 \mathrm{U} \mathrm{g}^{-1}$ ). Usually the phytate degradation during 
cereal dough fermentation is positively correlated with the endogenous phytase activity [32]. This fact was observed in the control formulations without added phytase, which displayed a $70 \%$ of phytate hydrolysis for whole wheat bread (WWF) and $46 \%$ for the $25 \%$ whole amaranth bread (WAF25) compared to raw materials (Table 2). However, endogenous Ins $P_{6}$ hydrolysis in samples with the highest concentration of amaranth flour (WAF50) was not observed. The addition of exogenous phytases resulted in a further decrease in $\operatorname{lns} P_{6}$ contents which reached up to an $89 \%$ reduction relative to control samples. Ins $P_{5}$ contents, which also have a strong chelating potential on minerals [33] were also reduced to similar levels. Here, a better performance was found for bifidobacterial phytases compared to the control fungal phytase, especially in WWF and WAF25 breads: hydrolysis of $87-89 \%$ of Ins $P_{6}$ for bifidobacterial phytases compared to control breads, whereas hydrolysis was only between 28 and $74 \%$ for fungal phytase. A better $\operatorname{Ins} P_{6}$ hydrolysis by bifidobacterial phytases compared to a commercial fungal phytase has been previously reported in the treatment of cereals for infants [34]. In these studies more than $90 \%$ Ins $P_{6}$ hydrolysis was reported for the $B$. pseudocatenulatum enzyme, whereas hydrolysis of $68 \%$ were obtained with a Aspergillus niger phytase. Factors like $\mathrm{pH}$ and temperature drastically affect phytase activity [23] and may account for these differences. In this regard it is worth mentioning that the bifidobacterial enzymes showed a high thermal stability [23] that allows their activity during the first stage of baking. Also, it cannot be excluded that inhibitory substances present in the flours were differentially affecting the activity of fungal and bifidobacterial phytases. In WAF50 breads phytate hydrolysis by the added phytases reached values from 47 to $70 \%$, although 
these products still contained a substantial amount of phytate (up to $3.5 \mu \mathrm{mol} \mathrm{g}$ ${ }^{1}$, Table 2). This can be attributed to the elevated $\operatorname{Ins} P_{6}$ concentration present in this formulation, to the presence of likely phytase inhibitory substances in the amaranth flour or to a feedback inhibition on phytase activity by phosphate released to the medium [24]. In these samples, a better $\operatorname{Ins} P_{6}$ degrading activity for the B. pseudocatenulatum enzyme, compared to B. longum spp. infantis, was determined. This was also observed during the phytase treatment of infant cereals, which contained more than $2 \mu \mathrm{mol} \mathrm{g}^{-1}$ of $\operatorname{Ins} P_{6}$ [34].

The biochemical characterization of $B$. longum spp. infantis and $B$. pseudocatenulatum phytases showed that these enzymes, although displaying a high specificity for phytate, are not able to degrade $\operatorname{Ins} P_{3}$. Therefore this myoinositol phosphate is accumulated during the reaction [23]. $\operatorname{Ins} P_{3}$ accumulation was also observed when $\operatorname{Ins} P_{6}$ hydrolysis products were analyzed in bacterial cultures of these bifidobacteria $[19,35]$ or when the purified enzymes were employed during the dextrinization step of infant cereals [34]. In addition, other whole grain breads made with doughs fermented by bifidobacteria also showed accumulation of $\operatorname{Ins} P_{3}$ [22]. In contrast to this, $\operatorname{Ins} P_{3}$ accumulation was not observed in the present study. This suggests that the high activity of the cereal/pseudocereal endogenous phytases and/or unspecific phosphatases present in our flours are responsible for a further degradation of $\operatorname{Ins} P_{3}$ to lower myo-inositol phosphates ( $\operatorname{Ins} P_{2}$ and $\left.\operatorname{Ins} P_{1}\right)$ or myo-inositol. This indicates that the hydrolysis profile depends not only on the utilized phytases but also on the flour (raw material).

\section{Phytase treatments and phytate/mineral ratios}


The substitution of $50 \%$ of wheat flour by whole amaranth flour (WAF50) increased the amount of $\mathrm{Ca}$ from $43 \pm 3$ to $125 \pm 13 \mathrm{mg} / 100 \mathrm{~g}$. The amount of Fe and $\mathrm{Zn}$ was also increased from $1.1 \pm 0.1$ to $3.2 \pm 0.6 \mathrm{mg} / 100 \mathrm{~g}$ and from $2.3 \pm 0.2$ to $3.3 \pm 0.7 \mathrm{mg} / \mathrm{g}$, respectively (Table 3 ). In general, white bread has a low mineral content and should be supplemented to meet the daily requirements for different elements. In this context, whole grain breads are known to be richer sources of macro- and microelements than breads made of refined flours. The amount of Fe in whole wheat bread (WWF) was close to the amount in breads with $25 \%$ of whole amaranth flour (WAF25), while the amount of $\mathrm{Zn}$ was similar to the content in bread with $50 \%$ of amaranth (WAF50). Table 3 shows the contributions of mineral intake from bread to the dietary reference intakes (DRIs) given by the Food and Nutrition Board of the Institute of Medicine, National Academy of Science [36], taking into account the World Health Organization's recommendation of a daily intake of $250 \mathrm{~g}$ of bread [7]. When expressed in terms of DRIs, the control breads (WF and WWF) contribute between 8.2 and $9.0 \%$ of the Ca recommended for adults, whereas the breads incorporating amaranth contribute to increased intakes of this mineral, ranging from 17.6 to $23.8 \%$ of DRIs (WAF25 and WAF50, respectively). Regarding Zn, consumption of the WF bread would provide $38.8 \%$ for men and $53.4 \%$ for women of the daily requirement in adults; while WAF50 breads could provide $57 \%$ and $78 \%$ of the daily requirements in men and women, respectively. The same trend was observed with $\mathrm{Fe}$, where $25 \%$ amaranth flour substitution could supply near $50 \%$ of the daily requirement of this mineral in men and $22 \%$ in women. Notwithstanding, it is known that the bioavailability of minerals depends on the presence of phytates, which act as inhibitors of mineral uptake and have 
adverse effects on their bioavailability, owing to the formation of insoluble complexes $[37,38]$. Solubility of nutrients in the gastrointestinal environment (or bioaccessibility) is a pre-requisite for absorption by enterocytes in the intestine. In this sense, the predicted intakes that are derived from DRIs for the minerals analyzed in this study are certainly overestimated due to the presence of phytate [7]. Small amounts of phytate can seriously compromise minerals bioavailability. As an example, more than $0.135 \mu \mathrm{mol} \mathrm{g}{ }^{-1}$ of $\operatorname{Ins} P_{6}$ in fortified bread (dry basis), can affect iron absorption in humans [39]. The phytate/minerals molar ratios are used to predict this inhibitory effect $[12,40]$ and in this regard a series of values have been established representing critical thresholds (Table 3). Mineral bioavailability was predicted for calcium, iron and zinc in our samples based on these ratios. Due to the high calcium content, their $\operatorname{lns} P_{6} /$ mineral ratios were below the critical threshold in all samples. These ratios were further decreased by the use phytases. For iron and zinc, bifidobacterial phytases generally proved to be more effective than the control fungal phytase in reducing the ratios below the critical values $(<1$ and $<5$, respectively). Thus, molar ratios for iron were still above the critical value in WAF25 samples treated with the fungal phytase, whereas these ratios were below this value in samples with bifidobacterial phytases. Owing to the high phytate contents, breads with $50 \%$ amaranth flour still displayed values indicative of an inhibition in $\mathrm{Fe}$ and $\mathrm{Zn}$ availability. In these samples inhibition was only relieved for zinc by treatment with the B. pseudocatenulatum phytase, further confirming the better performance of this enzyme in cereal mixes [34].

\section{Conclusions}


We showed that a $25 \%$ of amaranth flour can be used as a replacement for wheat flour in bread formulations. This produces an improvement in the nutritional value of bread with only a slight depreciation in quality. Bifidobacterial phytases are able to lower $\operatorname{Ins} P_{6}$ levels during the breadmaking process. The reduction in breads with $25 \%$ amaranth leads to $\operatorname{Ins} P_{6}$ levels that are below the threshold of inhibition of mineral availability. Furthermore, due to the food-grade nature of bifidobacteria, the use of their phytases during food manufacture represents an attractive strategy to produce whole grain products (from cereals and pseudocereals) with enhanced nutritional quality.

\section{Acknowledgments}

This work was financially supported by grants AGL2011-22669 and Consolider Fun-C-Food CSD2007-00063 from the Ministry of Economy and Competitiveness (MINECO) and PROMETEO/2012/064 from the Generalitat Valenciana, Spain. The contract of I. García-Mantrana from the Consolider FunC-Food Project is gratefully acknowledged. We thank Dr. Dinoranz Vélez and Dr. Vicenta Devesa from the Trace Elements Group (IATA-CSIC) for their help with the MARS method for samples digestion. 


\section{REFERENCES}

1. Snider M, Liebman M (1992) Calcium additives and sprouted wheat effects on phytate hydrolysis in whole wheat bread. J Food Sci 57:118-120

2. Isserlyska D, Karadjov G, Angelov A (2001) Mineral compositions of Bulgarian wheat bread. Eur Food Res Technol 213:244-245

3. Katina K, Arendt E, Liukonnen KH, Autio K, Flander L, Poutanen K (2005) Potencial of sourdough for healthier cereal products. Trends Food Sci Tech $16: 104-112$

4. Aleixandre A, Miguel M (2008) Dietary fiber in prevention and treatment of metabolic syndrome. Crit Rev Food Sci 48:905-912

5. Gamel TH, Linssen JP, Mesallam AS, Damir AA, Shekib LA (2006) Seed treatments affect functional and antinutritional properties of amaranth flours. $\mathrm{J}$ Sci Food Agric 86:1095-1102

6. Bodroza-Solarov M, Filiocev B, Kevresan Z, Mandic A, Simurina O (2008) Quality of bread supplemented with popped Amaranthus cruentus grain. J Food Process Eng 31:602-618

7. Sanz-Penella JM, Wronkowska M, Soral-Smietana M, Haros M (2013) Effect of whole amaranth flour on bread properties and nutritive value. LWT-Food Sci Technol 50:679-685

8. Giuseppe C, Coda R, De Angelis M, Di Cagno R, Carnevalli P, Gobbetti M (2009) Long-term fangal inhibitory activity of water-soluble extract from Amaranthus spp. Seeds during storage of gluten-free and wheat flour breads. Int J Food Microbiol 131:189-196 
9. Oszvald M, Tamás C Rakszegi M, Tömösközi S, Békés F, Tamás L (2009) Effects of incorporated amaranth albumins on the functional properties of wheat dough. J Sci Food Agr 89:882-889

10. Zapotoczny P, Markowski M, Majewska K, Ratajski A, Henryk K (2006) Effect of temperature on the physical, functional and mechanical characteristics of hot-air-puffed amaranth seeds. J Food Eng 76:469-476

11. Silva-Sánchez C, Barba de la Rosa AP, León-Galván MF, De Lumen BO, De León-Rodríguez A, González de Mejía E (2008) Bioactive peptides in amaranth (Amaranthus hypochondriacus) seed. J Agric Food Chem 56:12331240

12. Hurrell RF (2003) Influence of vegetable protein sources on trace element and mineral bioavailability. J Nutr 133:2973S-2977S

13. Fretzdorff B, Brümmer JM (1992) Reduction of phytic acid during breadmaking of whole-meal breads. Cereal Chem 69:266-270

14. Nielsen MM, Damstrup ML, Dal Thomsen A, Rasmussen SK, Hansen A (2007) Phytase activity and degradation of phytic acid during rye bread making. Eur Food Res Technol 225:173-181

15. Reddy NR, Harland BF, Pierson MD (1989) Acumulation and occurrence of phytate forms in dry beans. Faseb J 3:A759

16. Cheryan M (1980) Phytic acid interactions in food systems. CRC Cr Rev Food Sci 13:297-335

17. Konietzny U, Greiner R (2003) Phytic acid: Properties and Determination. In: Caballero B, Trugo L, Finglas P (eds) Encyclopedia of Food Science and Nutrition, $2^{\text {nd }}$ edn. Elsevier, London 
18. Shi Y, Azab AN, Thompson MN, Greenberg ML (2006) Inositol phosphates and phosphoinositides in health and disease. Sub-Cell Biochem 39:265-292

19. Haros M, Carlsson NG, Almgren A, Larsson-Alminger M, Sandberg AS, Andlid T (2009) Phytate degradation by human gut isolated Bifidobacterium pseudocatenulatum ATCC27919 and its probiotic potential. Int J Food Microbiol $135: 7-14$

20. Sanz-Penella JM, Tamayo-Ramos JA, Haros M (2012) Application of Bifidobacteria as starter culture in whole wheat sourdough breadmaking. Food Bioprocess Technol 5:2370-2380

21. Maenz DD. (2001) Enzymatic characteristics of phytases as they relate to their use in animal feeds. In: Bedford MR, Partridge GG (eds) Enzymes in Farm Animal Nutrition. CABI Publishing, New York

22. Sanz-Penella JM, Tamayo-Ramos JA, Sanz Y, Haros M (2009) Phytate reduction in bran-enriched bread by phytase-producing Bifidobacteria. J Agric Food Chem 57:10239-10244

23. Tamayo-Ramos JA, Sanz-Penella JM, Yebra MJ, Monedero V, Haros M (2012) Novel phytases from Bifidobacterium pseudocatenulatum ATCC 27919 and Bifidobacterium longum spp infantis ATCC 15697. Appl Environ Microbiol 78:5013-5015

24. Haros M, Rosell CM, Benedito C (2001) Use of fungal phytase to improve breadmaking performance of whole wheat bread. J Agr Food Chem 49:54505454

25. Haros M, Bielecka M, Sanz Y (2005) Phytase activity as a novel metabolic feature in Bifidobacterium. FEMS Microbiol Lett 247:231-239 
26. Tanner JT, Barnett SA (1986) Methods of analysis for infant formula: Food and drug administration and infant formula Council Collaborative study, Phase III. J Assoc Off Anal Chem 69:777-785

27. Türk M, Sandberg AS (1992) Phytate degradation during breadmaking: effect of phytase addition. J Cereal Sci 15:281-294

28. Sanz-Penella JM, Collar C, Haros M (2008) Effect of wheat bran and enzyme addition on dough functional performance and phytic acid levels in bread. J Cereal Sci 48:715-721

29. Giannou V, Tzia G (2007) Frozen dough bread: Quality and textural behaviour during prolonged storage-Prediction of final product characteristics. $\mathrm{J}$ Food Process Eng 79:929-934

30. Martínez-Valverde I, Periago MJ, Ros G (2000) Nutritional meaning of the phenolic compounds from the diet. Arch Latinoam 50:5-18

31. Haros M, Rosell CM, Benedito C (2001) Fungal phytase as a potencial breadmaking additive. Eur Food Res Technol 213:317-322

32. Reale A, Konietzny U, Coppola R, Sorrentino E, Greiner R (2007) The importance of lactic acid bacteria for phytate degradation during cereal dough fermentation. J Agri Food Chem 55:2993-2997

33. Sandberg AS, Brune M, Carlsson NG, Hallberg L, Skoglund E, RossanderHulthén L (1999) Inositol phosphates with different numbers of phosphate groups influence iron absorption in humans. Am J Clin Nutr 70:240-246

34. Sanz-Penella JM, Frontela C, Ros G, Martinez C, Monedero V, Haros M (2012) Application of bifidobacterial phytases in infant cereals: Effect on phytate contents and mineral dialyzability. J Agric Food Chem 60:11787-11792 
35. Haros M, Bielecka M, Sanz Y (2007) Myo-inositol hexakisphosphate degradation by Bifidobacterium infantis. Int J Food Microbiol 117:76-84

36. NAS (2004) National Academy of Sciences. Institute of Medicine Food and Nutrition Board. Dietary Reference Intakes: Recommended Intakes for Individuals, vitamins, minerals and macronutrients

37. Sandström B, Sandberg AS (1992) Inhibitory effects of isolated inositol phosphates on zinc absorption in humans. J Trace Elem Elect H 6:99-103

38. Sanz-Penella JM, Laparra JM, Sanz Y, Haros M (2012) Bread supplemented with amaranth: Effect of phytates on in vitro iron absorption. Plant Food Hum Nutr 67:50-56

39. Sandberg AS, Hulthen LR, Turk M (1996) Dietary Aspergillus niger phytase increases iron absorption in humans. J Nutr 126:476-480

40. Ma G, Jin Y, Plao J, Kok F, Giusi B, Jacobsen E (2005) Phytate, Calcium, Iron and zinc contents and their molar ratios in foods commonly consumed in China. J Agric Food Chem 53:10285-10290 


\section{FIGURE CAPTIONS}

Figure 1. Flow diagram of the breadmaking process with different whole grain flours (wheat or amaranth) and bifidobacterial phytases. 
Table 1. Effect of treatment and formulation on the technological parameters of breads.

\begin{tabular}{|c|c|c|c|c|c|}
\hline Sample & Treatment & $\begin{array}{c}\text { Moisture } \\
\%\end{array}$ & $\begin{array}{l}\text { Specific volume } \\
\mathrm{ml} \mathrm{g}^{-1}\end{array}$ & $\begin{array}{l}\text { Width/Height } \\
\quad \mathrm{cm} \mathrm{cm}^{-1}\end{array}$ & $\begin{array}{c}\text { Firmness } \\
\qquad \mathbf{N}\end{array}$ \\
\hline WF & & $33.1 \pm 0.1^{\mathrm{e}}$ & $4.1 \pm 0.0^{9}$ & $1.6 \pm 0.0^{\mathrm{abc}}$ & $0.5 \pm 0.1^{a}$ \\
\hline WWF & C & $33.8 \pm 0.2^{\mathrm{fgh}}$ & $3.7 \pm 0.1^{d}$ & $1.5 \pm 0.0^{a}$ & $1.0 \pm 0.1^{\mathrm{cd}}$ \\
\hline WAF25 & & $31.5 \pm 0.1^{c}$ & $3.9 \pm 0.1^{\mathrm{fg}}$ & $1.9 \pm 0.0^{f}$ & $0.7 \pm 0.1^{b}$ \\
\hline WAF50 & & $34.3 \pm 0.5^{i}$ & $2.6 \pm 0.2^{a}$ & $2.0 \pm 0.0^{g}$ & $2.0 \pm 0.3^{g}$ \\
\hline WWF & & $33.4 \pm 0.5^{\text {ef }}$ & $3.8 \pm 0.1^{\text {def }}$ & $1.7 \pm 0.0^{\mathrm{bcd}}$ & $2.5 \pm 0.1^{\mathrm{h}}$ \\
\hline WAF25 & FP & $33.6 \pm 0.1^{\text {etg }}$ & $3.9 \pm 0.1^{\text {etg }}$ & $1.7 \pm 0.0^{\mathrm{bcd}}$ & $1.1 \pm 0.2^{\mathrm{cd}}$ \\
\hline WAF50 & & $32.5 \pm 0.1^{d}$ & $3.1 \pm 0.1^{c}$ & $1.8 \pm 0.1^{\text {ef }}$ & $1.9 \pm 0.2^{\mathrm{fg}}$ \\
\hline WWF & & $30.8 \pm 0.1^{a b}$ & $3.8 \pm 0.1^{\mathrm{de}}$ & $1.8 \pm 0.0^{\text {ef }}$ & $2.5 \pm 0.3^{h}$ \\
\hline WAF25 & PS & $30.4 \pm 0.1^{a}$ & $3.8 \pm 0.1^{\text {def }}$ & $1.7 \pm 0.0^{\mathrm{cde}}$ & $0.8 \pm 0.1^{b c}$ \\
\hline WAF50 & & $34.2 \pm 0.3^{\mathrm{hi}}$ & $2.8 \pm 0.1^{b}$ & $1.7 \pm 0.0^{\mathrm{cdef}}$ & $1.5 \pm 0.1^{\mathrm{e}}$ \\
\hline WWF & & $31.0 \pm 0.1^{b c}$ & $3.8 \pm 0.1^{\mathrm{de}}$ & $1.7 \pm 0.0^{\mathrm{abcd}}$ & $1.8 \pm 0.2^{f}$ \\
\hline WAF25 & IN & $33.5 \pm 0.1^{\text {ef }}$ & $4.0 \pm 0.1^{g}$ & $1.6 \pm 0.0^{a b}$ & $0.9 \pm 0.1^{\mathrm{cd}}$ \\
\hline WAF50 & & $34.1 \pm 0.2^{g h i}$ & $2.8 \pm 0.1^{b}$ & $1.8 \pm 0.0^{\text {det }}$ & $1.4 \pm 0.1^{\mathrm{e}}$ \\
\hline
\end{tabular}

WF: $100 \%$ wheat flour, WWF: $100 \%$ whole wheat flour, WAF25: $25 \%$ whole amaranth flour $/ 75 \%$ wheat flour, WAF50: 50\% whole amaranth flour/50\% wheat flour; C: control without phytase, FP: fungal phytase, PS: B. pseudocatenulatum phytase, IN: B. longum spp. infantis phytase;

${ }^{a-i}$ Mean \pm SD. Values followed by the same letter in the same column are not significantly different at $95 \%$ confidence level. 
Table 2. Effect of formulation on the myo-inositol phosphates levels in bread

\section{$\mu$ moles $\mathrm{g}^{-1}$ of bread (dry base)}

\begin{tabular}{|c|c|c|c|c|c|c|}
\hline Samples & Phytase & $\operatorname{lns} P_{6}$ & $\operatorname{lns} P_{5}$ & $\operatorname{lns} P_{4}$ & $\operatorname{lns} P_{3}$ & $\operatorname{Ins} P_{6}+\operatorname{Ins} P_{5}$ \\
\hline WF & - & n.d. & n.d. & n.d. & n.d. & n.d. \\
\hline \multirow[t]{4}{*}{ WWF } & C & $2.3 \pm 0.5^{\mathrm{e}}$ & $0.6 \pm 0.1^{\mathrm{e}}$ & $0.3 \pm 0.1^{d}$ & $0.5 \pm 0.1^{f}$ & $2.9 \pm 0.7^{c}$ \\
\hline & FP & $0.6 \pm 0.4^{\mathrm{ab}}$ & $0.1 \pm 0.1^{\mathrm{ab}}$ & $0.1 \pm 0.1^{a}$ & $0.1 \pm 0.1^{\mathrm{a}}$ & $0.7 \pm 0.7^{a}$ \\
\hline & PS & $0.3 \pm 0.1^{a}$ & $0.1 \pm 0.1^{\mathrm{ab}}$ & $0.1 \pm 0.1^{\mathrm{b}}$ & $0.3 \pm 0.1^{\mathrm{e}}$ & $0.5 \pm 0.1^{\mathrm{a}}$ \\
\hline & IN & $0.3 \pm 0.2^{a}$ & $0.1 \pm 0.1^{\mathrm{a}}$ & $0.1 \pm 0.1^{\mathrm{ab}}$ & $0.1 \pm 0.1^{\mathrm{a}}$ & $0.4 \pm 0.3^{a}$ \\
\hline \multirow[t]{4}{*}{ WAF25 } & C & $1.8 \pm 0.3^{\mathrm{cd}}$ & $0.3 \pm 0.1^{\mathrm{bcd}}$ & $0.1 \pm 0.1^{b}$ & $0.2 \pm 0.1^{\text {de }}$ & $2.1 \pm 0.4^{b}$ \\
\hline & $\mathrm{FP}$ & $1.3 \pm 0.1^{b c}$ & $0.2 \pm 0.1^{a b c}$ & $0.1 \pm 0.1^{\mathrm{ab}}$ & $0.1 \pm 0.1^{\mathrm{abc}}$ & $1.5 \pm 0.2^{b}$ \\
\hline & PS & $0.2 \pm 0.1^{a}$ & $0.1 \pm 0.1^{\mathrm{a}}$ & $0.1 \pm 0.0^{\mathrm{a}}$ & $0.1 \pm 0.0^{\mathrm{ab}}$ & $0.2 \pm 0.1^{a}$ \\
\hline & IN & $0.2 \pm 0.1^{\mathrm{a}}$ & $0.1 \pm 0.0^{\mathrm{a}}$ & $0.1 \pm 0.0^{\mathrm{a}}$ & $0.1 \pm 0.1^{\mathrm{abc}}$ & $0.3 \pm 0.1^{a}$ \\
\hline \multirow[t]{4}{*}{ WAF50 } & C & $6.8 \pm 0.2^{g}$ & $1.0 \pm 0.2^{\dagger}$ & $0.2 \pm 0.1^{c}$ & $0.2 \pm 0.1^{\mathrm{bcde}}$ & $7.8 \pm 0.5^{\mathrm{e}}$ \\
\hline & FP & $3.4 \pm 0.6^{\dagger}$ & $0.4 \pm 0.1^{\text {cde }}$ & $0.1 \pm 0.0^{\mathrm{ab}}$ & $0.1 \pm 0.1^{\mathrm{abc}}$ & $3.7 \pm 0.6^{d}$ \\
\hline & PS & $2.0 \pm 0.1^{\text {de }}$ & $0.3 \pm 0.1^{\mathrm{bcd}}$ & $0.1 \pm 0.1^{\mathrm{ab}}$ & $0.2 \pm 0.1^{\mathrm{abcd}}$ & $2.4 \pm 0.0^{b c}$ \\
\hline & IN & $3.5 \pm 0.3^{\dagger}$ & $0.5 \pm 0.1^{d e}$ & $0.1 \pm 0.0^{\mathrm{ab}}$ & $0.2 \pm 0.1^{\text {cde }}$ & $3.9 \pm 0.4^{d}$ \\
\hline
\end{tabular}

\footnotetext{
${ }^{\mathrm{a}-\mathrm{g}}$ Mean $\pm \mathrm{SD}, \mathrm{n}=3$. Values followed by the same letter in the same column are not significantly different at 95\% confidence level; WF: $100 \%$ wheat flour, WWF: 100\% whole wheat flour, WAF25: $25 \%$ whole amaranth flour $/ 75 \%$ wheat flour, WAF $50: 50 \%$ whole amaranth flour $/ 50 \%$ wheat flour; C: control without phytase FP: fungal phytase, PS: B. pseudocatenulatum phytase, IN: B. longum spp. infantis phytase; ${ }^{d}$.d.: not detected; Ins $P_{6-3}$ : hexakis, pentakis, tetrakis and tri phosphate of myo-inositol, respectively.
} 
Table 3. Effect of bread formulation on mineral dietary reference intake contribution and mineral availability prediction

\begin{tabular}{|c|c|c|c|c|c|c|c|c|c|c|c|c|c|c|c|}
\hline \multirow[t]{3}{*}{ Parameter } & \multirow[t]{3}{*}{ Units } & \multirow{3}{*}{$\begin{array}{l}\text { DRI (mg per } \\
\text { day) or } \\
\text { Ins } P_{6} / M^{2} \text { ineral } \\
\left(\mathrm{mol} \mathrm{mol}^{-1}\right)\end{array}$} & \multicolumn{13}{|c|}{ Bread Formulation } \\
\hline & & & \multirow[t]{2}{*}{ WF } & \multicolumn{4}{|c|}{ WWF } & \multicolumn{4}{|c|}{ WAF25 } & \multicolumn{4}{|c|}{ WAF50 } \\
\hline & & & & C & FP & PS & IN & C & FP & PS & IN & C & FP & PS & IN \\
\hline $\operatorname{lns} P_{6}$ & $\mu \mathrm{mol} \mathrm{g} \mathrm{dm}{ }^{-1}$ & & n.d. & 2.3 & 0.6 & 0.3 & 0.3 & 1.8 & 1.3 & 0.2 & 0.2 & 6.8 & 3.4 & 2.0 & 3.5 \\
\hline $\mathrm{Ca}^{\mathrm{a}}$ & 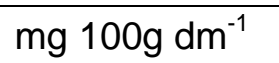 & & $48 \pm 8^{a}$ & \multicolumn{4}{|c|}{$43 \pm 3^{a}$} & \multicolumn{4}{|c|}{$92 \pm 15^{b}$} & \multicolumn{4}{|c|}{$125 \pm 13^{c}$} \\
\hline $\begin{array}{l}\text { DRI } \\
\text { contribution }^{b}\end{array}$ & $\%$ & Adults $(1000)^{\star *}$ & 9.01 & \multicolumn{4}{|c|}{8.16} & \multicolumn{4}{|c|}{17.6} & \multicolumn{4}{|c|}{23.8} \\
\hline $\operatorname{lns} P_{6} / \mathrm{Ca}^{c}$ & $\mathrm{~mol} \mathrm{~mol}^{-1}$ & $>0.24$ & 0.00 & 0.22 & 0.06 & 0.03 & 0.03 & 0.08 & 0.06 & 0.01 & 0.01 & 0.22 & 0.11 & 0.06 & 0.11 \\
\hline $\mathrm{Fe}^{a}$ & 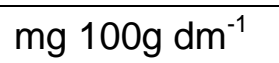 & & $1.1 \pm 0.1^{\mathrm{a}}$ & \multicolumn{4}{|c|}{$2.1 \pm 0.1^{b}$} & \multicolumn{4}{|c|}{$2.0 \pm 0.1^{b}$} & \multicolumn{4}{|c|}{$3.2 \pm 0.6^{c}$} \\
\hline \multirow{2}{*}{$\begin{array}{l}\text { DRI } \\
\text { contribution }^{b}\end{array}$} & $\%$ & Man (8) & 25.6 & \multicolumn{4}{|c|}{51.1} & \multicolumn{4}{|c|}{49.0} & \multicolumn{4}{|c|}{76.3} \\
\hline & & Woman $(18)^{\star}$ & 11.6 & \multicolumn{4}{|c|}{22.7} & \multicolumn{4}{|c|}{21.8} & \multicolumn{4}{|c|}{33.9} \\
\hline $\operatorname{lns} P_{6} / \mathrm{Fe}^{c}$ & $\mathrm{~mol} \mathrm{~mol}^{-1}$ & $>1$ & 0.0 & 6.0 & 1.6 & 0.8 & 0.8 & 4.9 & 3.5 & 0.5 & 0.5 & 11.7 & 5.9 & 3.4 & 6.0 \\
\hline $\mathrm{Zn}^{a}$ & $\mathrm{mg} 100 \mathrm{~g} \mathrm{dm}^{-1}$ & & $2.3 \pm 0.2^{a}$ & \multicolumn{4}{|c|}{$3.6 \pm 0.2^{b}$} & \multicolumn{4}{|c|}{$2.3 \pm 0.2^{a}$} & \multicolumn{4}{|c|}{$3.3 \pm 0.7^{b}$} \\
\hline \multirow{2}{*}{$\begin{array}{l}\text { DRI } \\
\text { contribution }^{b}\end{array}$} & $\%$ & Man (11) & 38.8 & \multicolumn{4}{|c|}{62.3} & \multicolumn{4}{|c|}{40.1} & \multicolumn{4}{|c|}{57.0} \\
\hline & & Woman (8) & 53.4 & \multicolumn{4}{|c|}{85.7} & \multicolumn{4}{|c|}{55.2} & \multicolumn{4}{|c|}{78.4} \\
\hline $\operatorname{lns} P_{6} / \mathrm{Zn}^{c}$ & $\mathrm{~mol} \mathrm{~mol}^{-1}$ & $>5$ & 0.0 & 4.7 & 1.1 & 0.6 & 0.6 & 9.1 & 3.7 & 0.6 & 0.6 & 16.2 & 6.8 & 4.0 & 7.0 \\
\hline
\end{tabular}

${ }^{a}$ Values followed by the same letter in the same row are not significantly different at 95\% confidence level; dm, dry matter; n.d., not detected

${ }^{b} \mathrm{DRI}$ (Dietary Reference Intakes) contribution (\%) for a daily average intake of $250 \mathrm{~g}$ of bread if the mineral absorption inhibitors are absent. The values in parenthesis are recommended dietary allowances and adequate intakes for individuals between 19 and $>70$ years, except for: * (between 31 and $>70$ years), and ${ }^{* *}$ (men between 19 and 70 years, women between 19 and 50 years); Food and Nutrition Board, Institute of Medicine, National Academy of Science, 2004. ${ }^{c}$ Threshold ratios (Ins $P_{6} /$ mineral) for mineral availability inhibition; Ins $P_{6}$ : myo-inositol hexakisphosphate; minerals: Ca, Fe or Zn; WF: $100 \%$ wheat flour, WWF: 100\% whole wheat flour, WAF $25: 25 \%$ whole amaranth flour $/ 75 \%$ wheat flour, WAF50: $50 \%$ whole amaranth flour/50\% wheat flour; C: control without phytase,

FP: treatment with fungal phytase, PS: treatment with B. pseudocatenulatum phytase, IN: treatment with $B$. longum spp. infantis phytase 
Figure 1

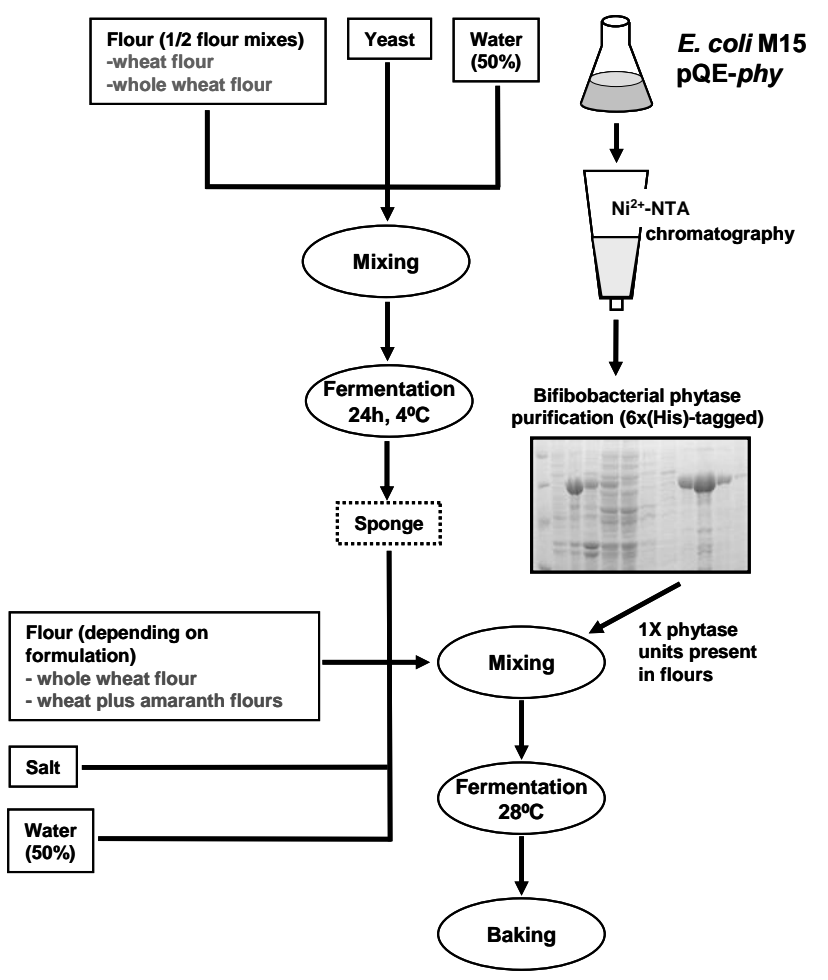

